\title{
Technical traditions and unquestioned assumptions : the case of pottery in Michoacan
}

Sander E. Van der Leeuw, Dick A. Papousek and Anick Coudart

\section{OpenEdition}

\section{Electronic version}

URL: https://journals.openedition.org/tc/691

DOI: $10.4000 /$ tc.691

ISSN: 1952-420X

\section{Publisher}

Éditions de l'EHESS

\section{Printed version}

Date of publication: 1 November 1992

ISSN: 0248-6016

\section{Electronic reference}

Sander E. Van der Leeuw, Dick A. Papousek and Anick Coudart, "Technical traditions and unquestioned assumptions : the case of pottery in Michoacan", Techniques \& Culture [Online], 17-18| 1992, Online since 10 January 2006, connection on 29 September 2022. URL: http:// journals.openedition.org/tc/691 ; DOI: https://doi.org/10.4000/tc.691

This text was automatically generated on 29 September 2022.

All rights reserved 
Technical traditions and unquestioned assumptions : the case of pottery in Michoacan

Sander E. Van der Leeuw, Dick A. Papousek and Anick Coudart 